\title{
The Decisionmaking Conference of the California Court of Appeal
}

\author{
John B. Molinari*
}

Dean Roscoe Pound pointed out, over a quarter of a century ago, that the most efficient appellate court is one of three judges. ${ }^{1}$ At about the same time the Honorable Raymond E. Peters, ${ }^{2}$ then Presiding Justice of Division One of the three-judge District Court of Appeal of the State of California in the First Appellate District, ${ }^{3}$ determined that it would add not only to the efficiency of his court but also to the quality of its work if the three judges would participate in some sort of an intimate conference prior to oral argument which, through a full and free discussion of the cases, would focus upon each case the combined intelligence of the three judges.

When Justice Peters was appointed to the district court of appeal in 1939, the California appellate courts followed a general practice under which the justices obtained their first knowledge of a case at oral argument. The rationale behind this procedure was that the justices could approach each case with a completely open mind and without any preconceived notions about the merits of the case before they heard the argument. ${ }^{4}$ But Justice Peters was convinced that the brevity of time necessarily allotted for oral argument made it difficult for the justices operating under this procedure to obtain a proper understanding of the case. He felt strongly that because the judges were not thoroughly familiar with the case at the time of argument-a fact known to the lawyers-both the judges and attorneys had a tendency to become indifferent to oral argument. As a result, oral argument usually consisted of a recital of the facts and the parties' general contentions instead of a detailed discussion of the decisive issues. Justice Peters was also concerned that the prevailing practice according to which one judge prepared the opinion of the court after oral argument, without full discussion with his associaties, had a tendency to produce a "one-man decision." 50 cope with these

* Presiding Justice, Court of Appeal of California, First Appellate District, Division Onc.

1. See R. Pound, Appellate Procedure in Civil Cases 383-84 (1941).

2. Currently Associate Justice of the Supreme Court of California.

3. Now the Court of Appeal of the State of California, lirst Appellate District, Division One.

4. Hyde, Appellate Court Decisions, 28 A.B.A.J. 808, 809 (1942).

5. Peters, Five Years of the Conference System, 19 CALIF. ST. B.J. 399, 400 (1944). 
problems Justice Peters prevailed upon his two associates in June 1939 to adopt a conference system, which not only became the first to be adopted by a reviewing court in California, but also served as a model for the conference systems which all of the other California intermediate appellate courts have since adopted.

In order to properly focus upon the conference-working methods of the California court of appeal and to observe these methods in their proper perspective, it is expedient to review briefly the use of the conference system and its variations in relation to the appellate decisionmaking process generally.

\section{THE DECISIONMAKING PROCESS AND THE CONFERENCE SYSTEM}

In general, cases are determined by a majority vote of judges. ${ }^{6}$ This decision may be declared in one of two ways: By a short concise order entered upon the records of the court merely indicating the affirmance or reversal of the lower court decision or the granting or denial of a petititon; or by a written opinion stating the reasons underlying the court's decision. ${ }^{7}$ In California, because of constitutional mandate, ${ }^{8}$ decisions of both the supreme court and the courts of appeal that determine causes must be in writing with the reasons stated. ${ }^{9}$

In deciding a case, the ideal method is for all of the judges to study the briefs and the record in each case. Where the case is to be orally argued, this study should be made before argument. A conference of the judges should then be held in order to ascertain each judge's views of the case and to ascertain if any of the judges has discovered points that have not been briefed or have been incompletely

6. See K. Llewellyn. The Common laiw Tradition-Deciding Appeals (1960) for an incisive, instructive and comprehensive analysis of the workings of the judicial process. (1961).

7. Leflar, Some Observations Concerning Judicial Opinions, 61 COLUM. L. REv, 810

8. CAL. Const. art. VI, $\S 14$.

9. A written opinion is not required for certain appellate court decisions that have been interpreted as falling outside the definition of "causes," such as the initial act issuing or declining to issue a prerogative writ on an ax parte application, Funeral Directors Ass'n v. Board of FuneraI Directors, 22 Cal. 2d 104, 106, 136 P.2d 785, 786 (1943), the granting of a motion to dismiss an appeal, People v. Brown, 149 Cal. App. 2d 175, 176, 307 P.2d 949 (1957), the deniaI of a petition for. rehearing, and, in the supreme court, the denial of a petition for a hearing after the decision of the court of appeal becomes final, Metropolitan Water Dist. v. Adams, 19 Cal. 2d 463, 472, 122 P.2d 257, 262 (1942). If a petition for hearing or rehearing is granted, the matter qualifies as the "determination of a cause" and an opinion must be written, as is the case where an alternative writ is issued. $I d$. 
briefed. This conference should be held before oral argument so that each judge will be thoroughly familiar with the case at the time of argument. The judges should reach only a tentative decision at the conference, thus affording an opportunity to bring the matter up again in conference after oral argument for a reassessment of the case and for final decision. ${ }^{10}$ If there is to be no oral argument a decision should be reached at the conference.

Because of the ever-increasing volume of litigation and the pressure upon the courts to dispose of cases expeditiously, the "ideal method" of deciding cases is generally not attainable. Each of the judges simply does not have the time to study the briefs and the record in each case. Thus, the "ideal method" must of necessity yield to methods less comprehensive in scope, yet calculated to obtain good results while permitting the court to keep up its work. We thus have a variety of forms of conference in the appellate courts in this country.

Although there are variations in the work methods in the various courts, the vast majority have adopted some form of conference system to enable the judges to exchange views on the principal issues involved in the case and to vote on the decision. In this respect they are similar to the "ideal system." They deviate from the "ideal system" because it is necessary to make accommodations for the inability of all of the judges to find time to study the record and the briefs of each case. In this regard the most important single device that has been developed for the purpose of informing the judges of the important issues in the case is the use of a complete and exhaustive memorandum. This memorandum, which is prepared by one of the judges in conjunction with his law clerk, consists of a detailed statement of the facts in the case (with transcript references), the contentions of the parties, an analysis of the cases and authorities relied upon by the parties, and the results, if any, of independent research. When completed this memorandum is distributed to each of the judges, together with copies of the briefs."

A significant aspect of the conference system in most

10. See C.E. Hughes, The Supreme Court of the United States 59 (1928); A. Vanderbilt, Minimum Standards of Judicial administration 438-43 (1949); Carter, Methods of Work in Courts of Review. 12 ILL. L. Rev. 231, 235 (1917).

11. With respect to the decisionmaking process in cases where written opınions are required, one of two methods is generally used. In some courts the vote is tentative and advisory only, allowing the judge to whom the writing of the opinion is assigned the freedom to reach the result that his research and later discussion with his colleagues warrants. In others the emphasis is on reaching a decision before assignment, and the opinion must be made in accordance with the vote taken at the conference. A.B.A. Section of Judicial Administration. Internal Operating Procedures of.Appellate Courts 6, 9-11 (1961). 
jurisdictions is that in cases where there is oral argument, the conferences are held after oral argument. Some hold them on the same day, some the next, others within three days, a few at variable times, and some when the draft of an opinion is ready for discussion. ${ }^{12}$

\section{THE CALIFORNIA COURT OF APPEAL}

In California there are five judicial districts, each of which contains a court of appeal with one or more divisions each consisting of a presiding justice and two or more associate justices. Each division conducts itself as a three-judge court, with the concurrence of two judges present at the oral argument required for a judgment. ${ }^{13}$

The work of the courts of appeal is divided into two main categories-opinion writing and passing on petitions for rehearing and applications for writs. In performing this work each division has adopted a conference system fashioned after that suggested by Justice Peters as a necessary adjunct to its internal working procedures. ${ }^{14}$

Since the courts of appeal are the primary courts of appeal for practically all cases, a major part of the internal procedure of each division is devoted to opinion writing. The California Constitution requires that cases be calendared for argument. ${ }^{15}$ Each division places cases on a calendar for hearing and oral argument on certain days each month. At the time the calendar is prepared assignments for opinion writing are made. The particular judge to whom the case is assigned prepares prior to oral argument a calendar memorandum in which he discusses the salient facts, comprehensively analyzes the applicable law and the points and pertinent cases cited in the briefs, and makes a recommendation for affirmance or reversal.

Since the judges are busy with writing opinions in cases which have already been argued and with the considering of applications for writs and petitions for rehearing, the exigencies of the situation require that a judge initially entrusts the preparation of the calendar memorandum to his research assistant. During this process the judge

12. Id. at 5 .

13. CAL. Const. art. VI, § 3. See also CAL. Gov'T CODE $\$$ 69100-05 (West Supp. 1968).

14. The California courts of appeal are committed to the concept that the litigant ought to have the independent judgment of every judge on the court and that every member of the court ought to be familiar with every branch of the law. Cases are not assigned to a particular judgc because he is familiar with or is an expert on a special branch of the law. In most divisions the assignments are made on a rotational basis although in a few divisions the assignments are made by the presiding justice.

15. CAL. CONST. art. VI, § 3. 
reads the briefs and, if necessary, the record and engages in frequent discussion, analysis, and consultation with his research assistant.

The memorandum which emanates follows one of two styles. It is either in the form of an objective analysis of the facts, the applicable law, and the contentions of the respective parites; or in the form of an opinion, delineating the facts and the law in the context of the judge's reasoning and his recommendations as to the court's decision. The argument in favor of the latter method is that if the other judges concur in the recommendations and rationale time is saved because the opinion is essentially completed. The argument against the "opinion method" is that it is not sufficiently objective. Rather it tends towards the "one-man opinion" in that it is oriented to the views of the judge preparing the memorandum, thus giving that judge a superior and controlling influence. ${ }^{16}$

When the calendar memorandum is completed, a copy is distributed to each judge. In instituting the conference system, Justice Peters evisioned a procedure whereby each memorandum would be distributed to the judges at least three weeks before the conference so that each judge would have ample time to study the memoranda, the briefs, and where necessary, the transcripts, and to complete any independent research he felt impelled to make. Five years after the adoption of the conference system Justice Peters, in evaluating the conference system, noted that in his court the memoranda were distributed to each judge a week before the oral argument. ${ }^{17}$ In the intervening years, the workload of the judges has significantly increased. Where previously each judge wrote four opinions each month, he is now writing approximately six opinions and, in some divisions, sometimes as many as eight and nine. Since a calendar memorandum must be prepared in each case, and since each judge has only one law clerk to assist him, it is not always possible to complete and distribute each memorandum at least a week before argument. Some of the memoranda are not completed until a few days before, or even on the eve of oral argument. In these cases the judges have only enough time to read the memoranda and are unable to study the briefs or make any independent research before the conference. This

16. See Internal Operating Procedures of Appellate Courts, supra note 11 , at 14 15; A. VANDERBILT, Minimum Standards OF JUdicial AdMINISTRaTION, supra note 10, at 438443. But see Traynor, Some Open Questions on the Work of State Appellate Courts, 24 U. CIIt. L. Rev. 2II, 217 (1957), where Justice Traynor, commenting upon the California practice, states: "One can speak from experience that there is no danger here of passive assent, of the socalled one-man opinion. There are often cumulative intramural memoranda, sharpening the issue, sometimes compelling re-assignment if the majority shifts. . . ."

17. Peters, Five Years of the Conference System, supra note 5, at 401. 
unfortunate situation can only be alleviated by providing each court with more law clerks. In some of the courts the volume of work will also require the appointment of more judges. ${ }^{18}$

Under the conference system currently employed, the conference is usually held on the day before the first day set for oral argument, or at the most, several days before. When the judges come to conference each has read the memoranda in the cases which are to be discussed, and each has read the briefs and the pertinent parts of the record in the cases assigned to him. In addition, each of the judges may have made an independent study of a case assigned to a colleague, including a reading of the briefs, and the record if necessary. At this day-long conference the judges discuss and analyze each of the cases which have been set for oral argument on the ensuing calendar. Normally, between 15 and 18 cases are discussed. ${ }^{19}$ Each of the judges takes the laboring oar on the cases which have been assigned to him by detailing the facts, his analysis of the applicable law, and his reasoning. The judges exchange ideas, opinions, and then reach, if possible, a tentative decision. The reaching of a tentative decision does not, however, tend to close the minds of the judges to a different ultimate conclusion since such decision is merely advisory and in no way binding upon the judges. Essentially, it is a step in the decisionmaking process based upon the views of the judges on the principal issues as they have been studied and analyzed prior to oral argument. In many cases the judges cannot reach a tentative decision and they hold their opinion in abeyance pending oral argument and further conference.

As a result of this conference procedure each of the judges is well informed about the facts and the applicable law and is therefore better able to follow oral argument. In addition, the important issues are pinpointed so that the ensuring oral argument can be directed to them, thus avoiding unnecessary and time-consuming questions. The judges are in a better position to ask questions concerning matters about which they are in doubt and matters which counsel have either inadequately presented in their briefs or have not presented at all. In

18. The California Constitution provides that each division can consist of more than three judges. CAL. Const. art. VI, $\$ 3$.

19. Many appellate judges are of the opinion that an appellate court cannot adequately deal with more than twelve cases on each calendar. The experience of the several courts indicates, however, that since on each calendar there are a number of cases which are less difficult to decide than others, a court can efficiently handle as many as eighteen cases provided the court is furnished with adequate research assistance and a complete memorandum in each case. 
this fashion the limited time ${ }^{20}$ allotted to oral argument is useful and beneficial.

It is significant to note here that the conference system adopted by the California intermediate courts, as originally instituted by Justice Peters, is unique and differs generally from that practiced in most of the appellate courts, including the California supreme court, in that the conference is held before oral argument. As will be later pointed out, this need not be the only conference held by the court, although in most cases it is.

It is the practice of the court in one district to hold another conference, immediately or shortly after oral argument, to reevaluate the tentative decision previously reached, or to reach a decision if a tentative decision had not been reached. The courts in the remaining districts usually hold a post-argument conference only if no tentative decision had been reached or if the oral argument has raised doubts in the minds of any of the judges about the correctness of that decision; if a conference is not held after oral argument, the tentative decision is deemed the decision of the court. The only essential difference between the two practices is that in the former a post-argument conference is always held to reevaluate a tentative decision, while in the latter such a conference is not held where a tentative decision was reached unless a judge questions the tentative decision. If there are no doubts, it appears, in the interest of conserving the time of the court, that a conference should not be held.

Although it is expected that the opinion will be written in accordance with the majority vote reached at conference, it is a frequent occurrence that the judge assigned to write the opinion will change his mind following further study and research. In this situation he may request that another conference be held. If his revised views are accepted at this conference, he will write an opinion in accordance with them. If, however, the other two judges adhere to the initial view, the case is then reassigned by the presiding justice to another judge for the writing of the opinion. Instead of requesting a conference to express his revised views, the judge receiving the original assignment may choose to write an opinion expressing them with the hope that when circulated they will persuade his colleagues to join in his opinion.

When a draft of the proposed opinion is completed, it is circulated among the other two judges together with the records and briefs in the case. In considering this draft the other judges have the

20. Counsel for each party is allowed 30 minutes for oral argument. CAL. RuLes of COURT 22. 
benefit of the calendar memorandum, the discussion in conference, and the discussion at oral argument. They can then intelligently decide whether a reading of the briefs or the record is necessary, or whether further study is required. Before indicating whether or not he is willing to adopt an opinion, the individual judge may make comments and suggested modifications by way of a memorandum attached to the proposed opinion, or he may call for another conference to discuss the opinion. A judge may note his full or partial concurrence either with or without an opinion. In a three-man court the dissenting opinion may become the majority opinion if the third judge is persuaded by its rationale and the result it reaches, notwithstanding his predilections at conference. If the judge initially assigned to write the majority opinion for an unanimous court changes his mind after receiving the assignment, his opinion may become a dissenting opinion. In that case the presiding justice reassigns the case to the judge whose independent research indicates that he is best qualified to write the opinion.

The court of appeal also utilizes the conference system in its other work. In determining the merits of a petition for rehearing, for example, all of the judges read the petition, any answer thereto, and if necessary the opinion originally filed in the case. When the judges indicate that they are ready to discuss the matter, a conference is held to determine whether the petition should be granted or denied. At that conference the judge who wrote the opinion reports on the merits of the petition and on his analysis of the points therein made. The judges then discuss the arguments made in the petition and any answer and take a vote at the close of the discussion.

When an application for a writ is presented, each judge receives a copy of the petition and any opposition thereto. In some divisions each judge makes an independent study and then notes his vote on an "action" card or slip, although, if he desires, he may call for a conference. In most divisions, however, a conference is held on all such applications and the same assignment procedure is followed as in the assignment for opinion writing. The judge to whom the application was initially assigned makes a report of his analysis of the application and the opposition thereto, the merits are discussed, and a vote is taken. When the application is granted, the matter is calendared, and the procedure prescribed for opinion writing is followed.

\section{CONCLUSION}

The internal work methods of the California courts of appeal seek to reconcile the demand for the expeditious disposition of appeals 
with the salutary objective of maintaining a sound decisionmaking process and of insuring a high quality of the written opinions of its judges. After thirty years, it is clear that the conference system has justified itself as a vital cog in these work methods. When it is effectively meshed with the helpful oral argument the conference provides the key to effective decisionmaking. Further, where the pressures of a congested court calendar result in inadequate time for preparation or study of the memorandum, the pre-oral argument conference becomes crucial. The conference before oral argument more effectively provides the judges with knowledge of the issues than does the memorandum alone and thus aids in getting more helpful arguments. It calls to the judges' attention the essential contentions of the parties, allows time for reflection on the issues, and affords the opportunity to ask proper questions, and for counsel to answer them. This approach to the decisionmaking process prevents the one-man decision. Although the opinion of an appellate judge in the California court of appeal is largely the work of one man, the decision itself is the informed action of a majority of the judges who act in the case.

The conference system has worked in California because the judges have cooperated in making the system work. With the help of additional law clerks the system can operate more effectively because it will permit the holding of the conference long enough before oral argument to permit the judges to make a proper study of the case. In recent years there has been a growing tendency to minimize the importance of oral argument, yet helpful oral argument following a meaningful conference of the judges is an invaluable function of the decisionmaking process. However, because of the large volume of cases, argument must be limited. The problem, therefore, is to get the most out of oral argument. To this end much could be accomplished if counsel could be advised well in advance of oral argument of the issues and questions which are of concern to the court and vital to the disposition of the cause. Such a procedure would prevent waste of time and would stimulate counsel to a more effective preparation. Of course, such a practice can only be put into effect if the conference is held several weeks in advance of oral argument. Needless to say, these objectives, long ago envisioned by Justice Peters, can only be accomplished through the effective cooperation of the bench and bar. 